\title{
OPEN Indirect effects of invasive rat removal result in recovery of island rocky intertidal community structure
}

\author{
Carolyn M. Kurle ${ }^{1 凶}$, Kelly M. Zilliacus ${ }^{2}$, Jenna Sparks ${ }^{2,5}$, Jen Curl ${ }^{3,6}$, Mila Bock ${ }^{2,7}$, \\ Stacey Buckelew ${ }^{3,8}$, Jeffrey C. Williams ${ }^{4}$, Coral A. Wolf ${ }^{3}$, Nick D. Holmes ${ }^{3,9}$, \\ Jonathan Plissner ${ }^{3}$, Gregg R. Howald ${ }^{3,10}$, Bernie R. Tershy ${ }^{2}$ \& Donald A. Croll ${ }^{2 \bowtie}$
}

Eleven years after invasive Norway rats (Rattus norvegicus) were eradicated from Hawadax Island, in the Aleutian Islands, Alaska, the predicted three-level trophic cascade in the rocky intertidal, with native shorebirds as the apex predator, returned, leading to a community resembling those on rat-free islands with significant decreases in invertebrate species abundances and increases in fleshy algal cover. Rats had indirectly structured the intertidal community via their role as the apex predator in a four-level trophic cascade. Our results are an excellent example of an achievable and relatively shortterm community-level recovery following removal of invasive animals. These conservation successes are especially important for islands as their disproportionately high levels of native biodiversity are excessively threatened by invasive mammals.

Invasive animals are a main driver of global biodiversity loss and can impact ecosystem function ${ }^{1-5}$. Invasive animal impacts are particularly disruptive on islands because islands usually have small numbers of species resulting in simplified food chains and limited functional redundancy, and those species typically have limited evolved defenses against herbivory, predation, and competition ${ }^{6}$. The direct effects of invasive animals on islands are well documented ${ }^{7-11}$, and there is increasing evidence of their multiple indirect effects as well ${ }^{6,12-15}$.

Invasive rats (Rattus spp.) are the most widespread and damaging invasive animals ${ }^{16,17}$. They are present on perhaps $90 \%$ of islands ${ }^{18,19}$, influence island biota both directly as competitors, predators, herbivores, and frugivores ${ }^{19-21}$, and indirectly via trophic cascades, cross ecosystem subsidies, propagule dispersal, and mutualist networks ${ }^{9,13,14,22-24}$.

Because of these deleterious impacts, the removal of invasive animals has become an important global conservation strategy, with over 900 successful animal eradications on almost 800 islands since $1950^{25}$. While the number, rate, and size of invasive animal eradications is increasing ${ }^{8,26-28}$, studies of the full benefits to island communities after invasive animal eradications are limited $\left(\right.$ but see $\left.^{8}\right)$. Longer-term post-eradication studies of island community recoveries from the direct and indirect impacts of invaders are even more limited ${ }^{29}$, as are recoveries from the effects of cross-ecosystem (e.g. near-shore marine vs. terrestrial) interactions.

Community recovery after invasive animal eradication is difficult to measure for many reasons, including natural stochasticity and uncertain baselines by which to compare altered landscapes. In addition, demonstration of community recovery requires study of the indirect effects of invaders, adequate measures of multiple community components, and a commitment to long-term monitoring. Therefore, the extent to which entire communities recover following invasive species eradication, and the time required for recovery, are much less

${ }^{1}$ Division of Biological Sciences, Ecology, Behavior, and Evolution Section, University of California San Diego, 9500 Gilman Dr, La Jolla, CA 92023, USA. ${ }^{2}$ Conservation Action Lab, University of California Santa Cruz, 115 McAllister Way, Santa Cruz, CA 95060, USA. ${ }^{3}$ Island Conservation, 2100 Delaware Ave, Suite 1, Santa Cruz, CA 95060, USA. ${ }^{4}$ US Fish and Wildlife Service, Alaska Maritime National Wildlife Refuge, 95 Sterling Highway, Suite 1, Homer, AK 99603, USA. ${ }^{5}$ Present address: Oikonos Ecosystem Knowledge, PO Box 2570, Santa Cruz, CA 95063, USA. ${ }^{6}$ Present address: Alaska Department of Fish and Game, Division of Wildlife Conservation, 1300 College Rd, Fairbanks, AK 99701, USA. ${ }^{7}$ Present address: Great Basin Institute, 16750 Mt. Rose Highway, Reno, NV 89511, USA. ${ }^{8}$ Present address: Axiom Data Science, 1016 W 6th Ave, Ste. 105, Anchorage, AK 99501, USA. ${ }^{9}$ Present address: The Nature Conservancy, 201 Mission Street \#4, San Francisco, CA 94105, USA. ${ }^{10}$ Present address: FreshWater Life, Telluride, CO, USA. ${ }^{\varpi}$ email: ckurle@ucsd.edu; dcroll@ucsc.edu 


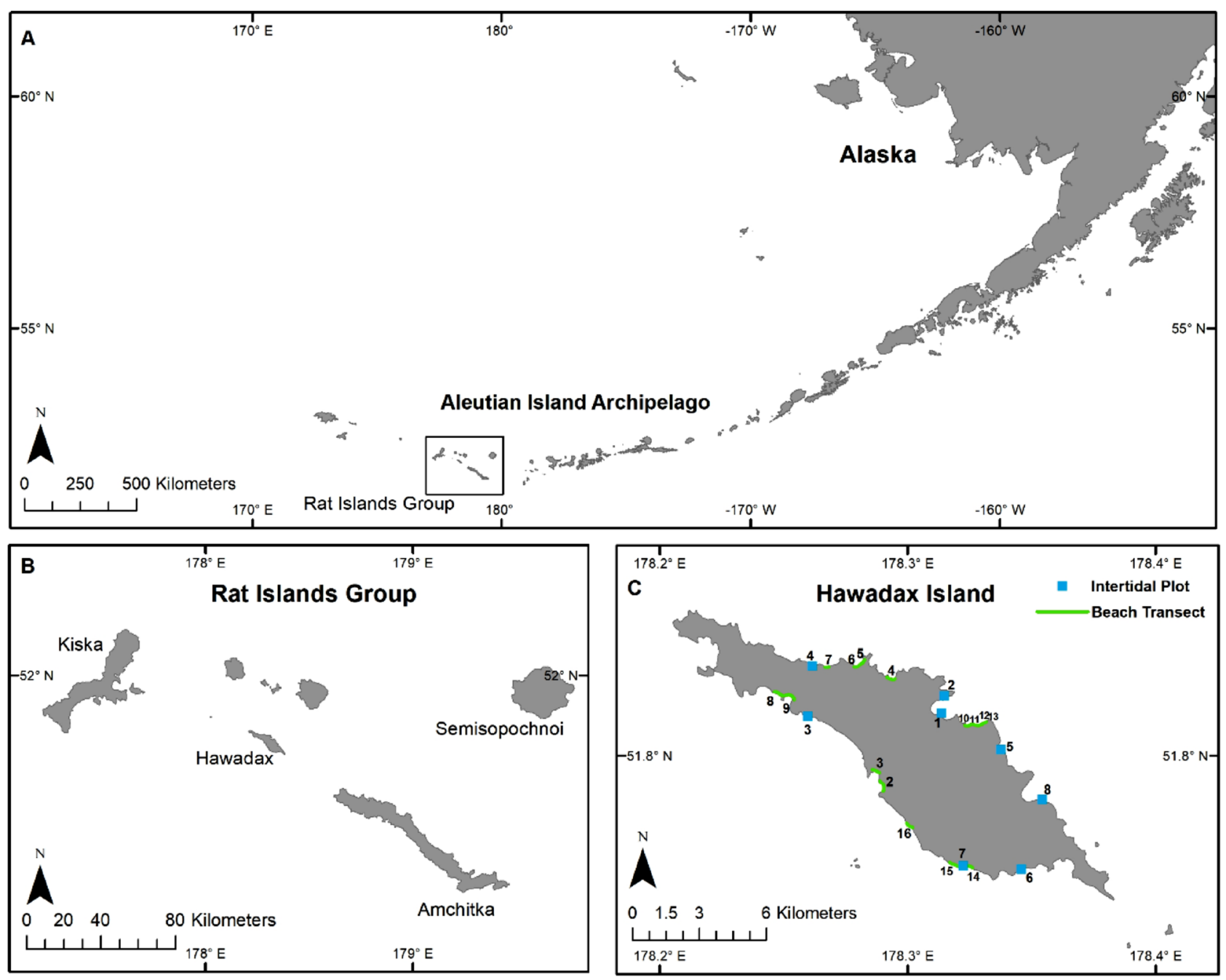

Figure 1. The (A) central Aleutian Archipelago, Alaska, USA contains the (B) Rat Islands Group, including Hawadax Island. The $(\mathbf{C})$ intertidal plots and beach transects surveyed on Hawadax Island. Intertidal plot 6 was only surveyed in 2008 and $2013^{35}$.

understood than the direct deleterious effects of invaders and the recoveries of multiple native species once invaders and their direct mechanisms of control (frequently predation) are removed (but see ${ }^{30,31}$ ).

Hawadax Island (previously known as Rat Island) is in the central Aleutian Island chain (Fig. 1). The island was likely invaded by Norway rats (R. norvegicus) when a Japanese ship went aground in the 1780 's, and invaded by Arctic foxes (Vulpes lagopus) following intentional introductions by fur traders in the $1800 \mathrm{~s}^{32}$. The combined impact of an introduced carnivore (foxes) and omnivore (rats) had multiple direct and indirect impacts ${ }^{33}$. For example, while archeological evidence from native Unangan (Aleut) habitation sites indicate marine birds were once common on Hawadax Island, rats and introduced foxes extirpated locally breeding seabirds, shorebirds, and land birds ${ }^{32}$.

Foxes were eradicated from Hawadax Island in $1984^{34}$, and rats were eradicated in 2008 using aerially broadcast rodenticide $\left(25-\mathrm{ppm}\right.$ brodifacoum ${ }^{32}$ ). Croll et al. ${ }^{33}$ reported on the direct effects of rat eradication after five years, demonstrating significant recoveries of terrestrial birds (Gray-crowned Rosy Finch [Leucosticte tephrocotis], Lapland Longspur [Calcarius lapponi-cus], Snow Bunting [Plectrophenax nivalis], and Song Sparrow [Melospiza melodia]) and shorebirds (Black Oystercatcher [Haematopus bachmani] and Rock Sandpiper [Calidris ptilocnemis], and the initial recolonization or recovery of marine birds (Tufted Puffin [Fratercula cirrhata], Leach's Storm-petrel [Oceanodroma leucohoa], and Glaucous-winged Gull [Larus glaucescens]). However, communitylevel changes resulting from indirect changes in trophic structure post-rat eradication are likely to take longer than the recovery of these directly impacted bird species ${ }^{30}$.

To measure the time required and potential for passive community recovery on an island after rat eradication, we measured abundances of shorebirds and multiple rocky intertidal species before (2008), and five (2013) and 11 (2019) years post-rat eradication on Hawadax Island. Previous comparisons in 2002-2004 by Kurle et al. ${ }^{12}$ of the rocky intertidal community composition on Islands in the Aleutian archipelago with and without invasive rats demonstrated a rat-mediated, four-level trophic cascade in which rats extirpated the shorebirds that forage on intertidal herbivores, leaving a system dominated by invertebrate herbivores (Fig. 2). Kurle et al. ${ }^{12}$ found that 
A

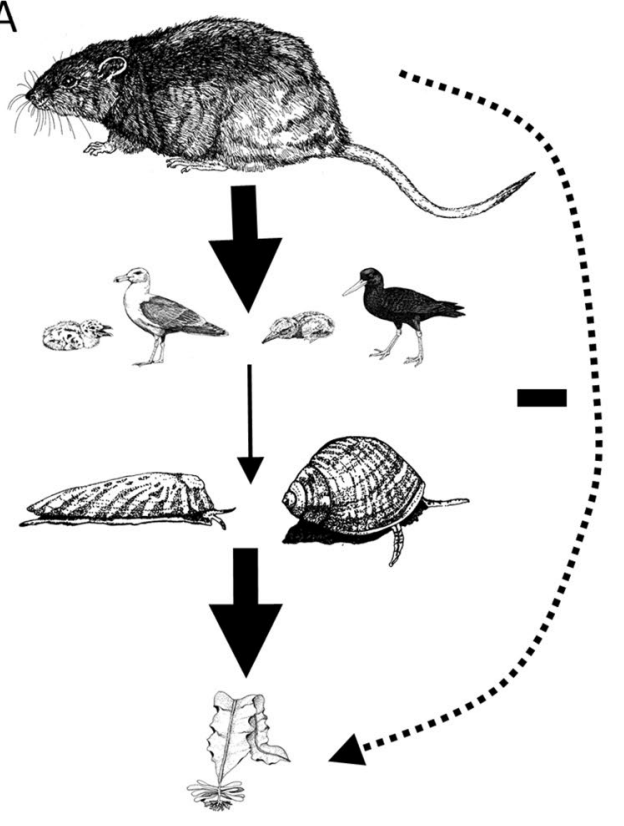

B

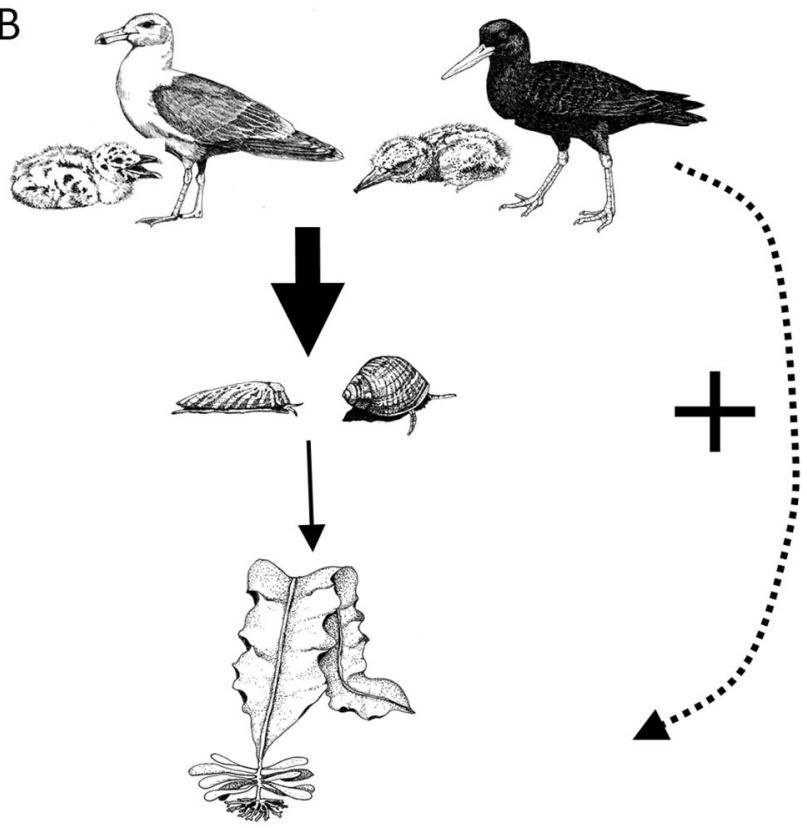

Figure 2. The presence of invasive rats on Aleutian Islands in Alaska creates a (A) four-level trophic cascade wherein rats negatively impact primary productivity, indirectly (dotted line) turning the rocky intertidal community into an invertebrate dominated system by depredating shorebirds and releasing intertidal grazers from bird predation pressure. On islands without rats, and presumably on islands in recovery after rat removal, such as Hawadax, the rocky intertidal becomes a (B) three-level trophic cascade wherein shorebirds depredate herbivorous invertebrates, thereby releasing algae from grazing pressure, and indirectly creating an algal dominated community. Birds also consume invertebrate non-grazers (e.g., mussels, anemones, seastars, and sponges), and their decreased abundances following rat removal may lead to increased availability of space in the rocky intertidal, further facilitating increases in algal cover. Figure modified from Kurle et al. ${ }^{12}$, Gena Bentall drew the images and C. Kurle created the figure.

$83 \%$ and $96 \%$ of islands could be assigned to their correct category of rat-infested or rat-free, respectively, based on the species composition of the rocky intertidal. Thus, we predicted that the rocky intertidal community on Hawadax Island would return to a state resembling a rat-free island given sufficient time for shorebird populations to recover to levels necessary to maintain the three-trophic level cascade typical of Aleutian Islands without rats.

We compared our long-term monitoring data collected on Hawadax Island pre- (2008) and post- (2013 and 2019) rat eradication to data contrasting rat-infested and rat-free Aleutian Islands measured in 2002-2004 from Kurle et al. ${ }^{12}$. Specifically, we sought to: (1) document longer-term recovery of breeding intertidal-feeding marine birds (Black Oystercatchers and Glaucous-winged Gulls), (2) examine changes in the marine rocky intertidal community related to the direct and indirect impacts of marine bird recovery, and (3) better understand the time required for recovery of marine rocky intertidal communities on islands after rat removal.

\section{Results}

Intertidal community. Predicted changes in the rocky intertidal community ${ }^{12}$ were largely not evident five years post-rat eradication (Table 1, Fig. 3, and Supplementary Fig. 1). However, by 11 years post-eradication, seven of 13 intertidal taxonomic groups showed significant predicted changes (Table 1, Fig. 3, Supplementary Fig. 1). Three species (anemones, mussels, and snails) met or exceeded the expected percent changes in abundance over time observed between islands with and without rats. One (sponges) was within less than $10 \%$ of the expected abundance change and three (fleshy algae, limpets, and sea stars) were within 17 to $35 \%$. The abundances of two (barnacles and tunicates) did not change as predicted, and the remaining four taxa were not measured in Kurle et al. ${ }^{12}$ (Fig. 3, Supplementary Table 1), so were not compared.

Beach transects. Glaucous-winged Gulls and Black Oystercatchers were significantly more abundant posteradication in 2013 and even more so in 2019 (Table 2, Fig. 3, Supplementary Table 1, Supplementary Fig. 1). Kurle et al. ${ }^{12}$ observed that Black Oystercatcher and Glaucus-winged Gull abundances were greater by $984 \%$ $(0.246 \pm$ SD 0.44 vs. $0.025 \pm$ SD 0.04 per km of shoreline) and $1014 \%$ (17.643 \pm SD 60.89 vs. $1.740 \pm$ SD 3.09 per $\mathrm{km}$ of shoreline), respectively, on islands without rats, whereas we observed $900 \%$ and $291 \%$ increases in their abundances between 2008 and 2019 (Table 2). In addition, we detected 19 active Glaucous-winged Gull nests and five active Black Oystercatcher nests post-eradication in 2019 compared to five nests and one nest, respectively, pre-eradication in 2008. 


\begin{tabular}{|c|c|c|c|c|c|c|c|}
\hline \multirow[b]{2}{*}{ Intertidal organism } & \multirow{2}{*}{\begin{tabular}{|l|} 
Pre \\
2008
\end{tabular}} & \multirow{2}{*}{\begin{tabular}{|l|} 
Post \\
2013 \\
\end{tabular}} & \multicolumn{2}{|c|}{2008 vs. 2013} & \multirow{2}{*}{\begin{tabular}{|l|} 
Post \\
2019
\end{tabular}} & \multicolumn{2}{|c|}{2008 vs. 2019} \\
\hline & & & $\mathrm{t}$ & $P$ & & $\mathbf{t}$ & $P$ \\
\hline \% Encrusting Algae & $47.9 \pm 3.1$ & $12.67 \pm 2.84$ & -8.3931 & $<0.0001^{*}$ & $5.9 \pm 1.3$ & -12.435 & $<0.0001^{\star}$ \\
\hline \% Fleshy Algae & $25.5 \pm 2.3$ & $26.09 \pm 2.36$ & 0.1858 & NS & $38.0 \pm 3.2$ & 3.151 & $0.0045^{*}$ \\
\hline$\%$ Geniculate Algae & $4.52 \pm 1.4$ & $3.62 \pm 0.98$ & -0.5258 & NA & $3.2 \pm 1.02$ & -0.763 & 0.2298 \\
\hline$\%$ Barnacles & $0.19 \pm 0.11$ & $0.21 \pm 0.14$ & 0.0965 & NS & $0.22 \pm 0.18$ & 0.136 & 0.4472 \\
\hline$\%$ Sponges & $9.44 \pm 2.4$ & $8.51 \pm 1.18$ & -0.3427 & NS & $3.69 \pm 0.84$ & -2.245 & $0.0263^{\star}$ \\
\hline$\%$ Tunicates & $1.99 \pm 0.5$ & $1.87 \pm 0.59$ & -0.1513 & NS & $2.12 \pm 0.69$ & 0.148 & 0.4424 \\
\hline Anemones $\mathrm{m}^{-2}$ & $66.6 \pm 20.9$ & $75.6 \pm 33.98$ & -0.1141 & NS & $17.1 \pm 10.9$ & -3.003 & $0.0061^{*}$ \\
\hline Isopods $\mathrm{m}^{-2}$ & $85.7 \pm 20.9$ & $10.68 \pm 2.82$ & -4.973 & $0.0001^{\star}$ & $1.69 \pm 0.63$ & -9.195 & $<0.0001^{\star}$ \\
\hline Limpets $\mathrm{m}^{-2}$ & $26.4 \pm 4.6$ & $23.19 \pm 4.95$ & -0.6545 & NS & $13.5 \pm 2.9$ & -2.219 & $0.0255^{\star}$ \\
\hline Mussels $\mathrm{m}^{-2}$ & $54.9 \pm 39.5$ & $3.43 \pm 3.15$ & -1.5288 & NS & $0.61 \pm 0.47$ & -1.934 & $0.0447^{*}$ \\
\hline Sea Stars $\mathrm{m}^{-2}$ & $8.1 \pm 3.08$ & $4.95 \pm 1.41$ & -0.2225 & NS & $1.59 \pm 0.72$ & -1.919 & $0.0395^{\star}$ \\
\hline Snails $\mathrm{m}^{-2}$ & $359.7 \pm 72.1$ & $191.04 \pm 45.16$ & -1.6452 & NS & $31.0 \pm 11.5$ & -5.452 & $<0.0001^{\star}$ \\
\hline Urchins $\mathrm{m}^{-2}$ & $20.3 \pm 5.5$ & $11.63 \pm 4.33$ & -1.2599 & NS & $10.4 \pm 2.34$ & -1.088 & 0.1481 \\
\hline
\end{tabular}

Table 1. The relative abundance of intertidal organisms measured before and after rat eradication $(\mathrm{Mean} \pm \mathrm{SE})$ (2008 and 2013: $\mathrm{n}=8 ; 2019: \mathrm{n}=7$ ). ${ }^{*} P$ is significant with $\alpha<0.05$.
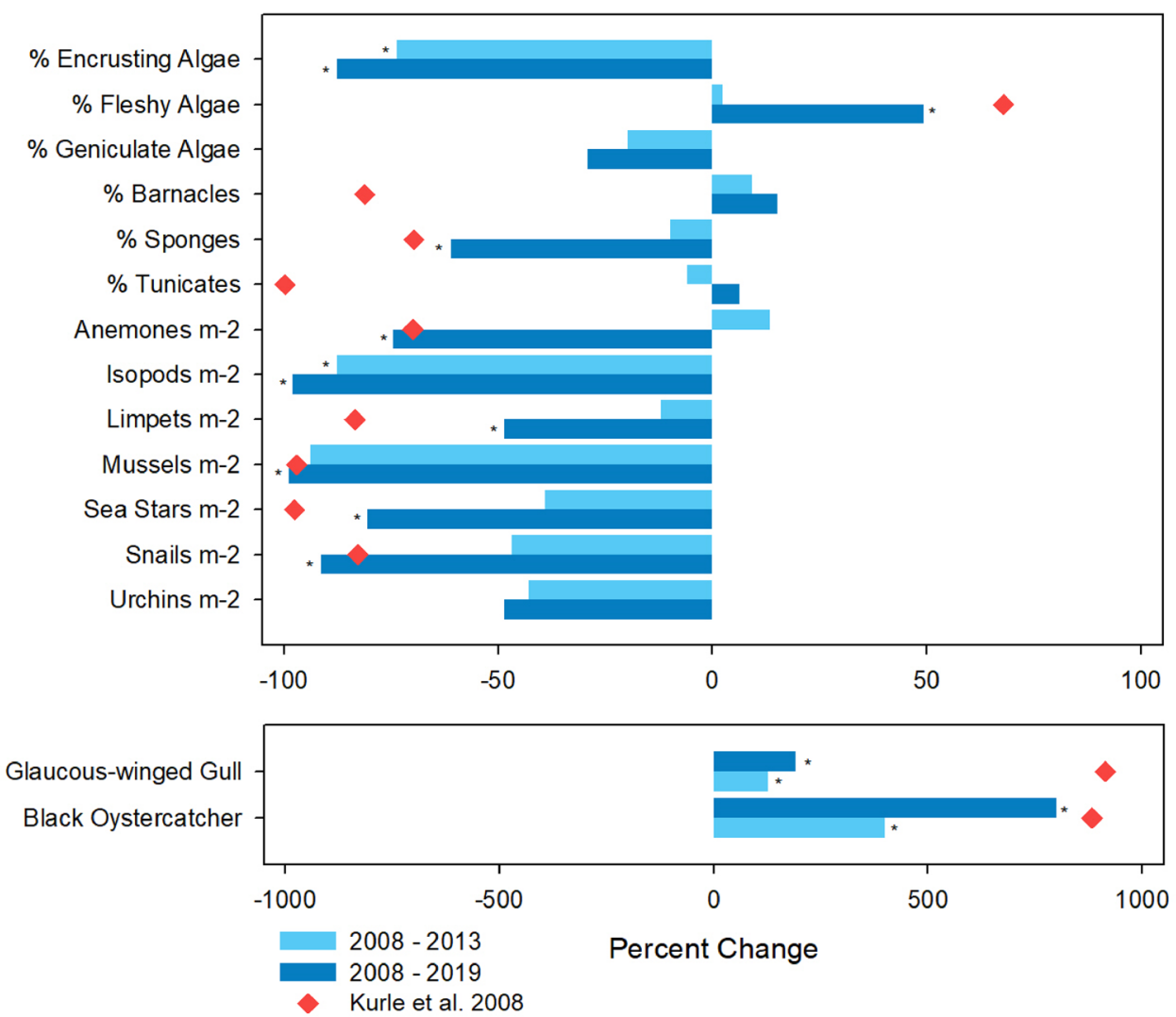

Figure 3. The percent change in algal, barnacle, sponge, and tunicate percent cover and mean number per $\mathrm{m}^{2}$ of invertebrates pre- vs. post-eradication (2008 vs. 2013 and 2019) measured from intertidal photo quadrats. * indicates significantly different data between 2008 and 2013 or 2008 and 2019, $p<0.05$. The red diamonds indicate the percent change between islands with rats and without rats from Kurle et al. ${ }^{12}$. No red diamond indicates an organism that was not measured in Kurle et al. ${ }^{12}$.

\section{Discussion}

Multiple studies document significant restoration of plant and animal species on islands following invasive animal removal ${ }^{5,8,36-39}$. In particular, positive growth in bird abundances post-eradication is especially welldocumented $^{31,40,41}$, including in the Aleutian Islands, where bird abundances increased significantly 5-10 years after invasive fox and/or rat eradication ${ }^{33,42-44}$. However, most of these studies focus on the reestablishment of 


\begin{tabular}{|c|c|c|c|c|c|c|c|}
\hline \multirow[b]{2}{*}{ Species } & \multirow{2}{*}{\begin{tabular}{|l|} 
Pre \\
2008 \\
\end{tabular}} & \multirow{2}{*}{\begin{tabular}{|l|} 
Post \\
2013 \\
\end{tabular}} & \multicolumn{2}{|l|}{2008 vs. 2013} & \multirow{2}{*}{\begin{tabular}{|l|} 
Post \\
2019 \\
\end{tabular}} & \multicolumn{2}{|l|}{2008 vs. 2019} \\
\hline & & & Chi Square & $P$ & & Chi Square & $P$ \\
\hline Black Oystercatcher & $0.001 \pm 0.001$ & $0.005 \pm 0.001$ & 15.7081 & $<0.0001^{\star}$ & $0.009 \pm 0.002$ & 17.8115 & $<0.0001^{\star}$ \\
\hline Glaucous-winged Gull & $0.023 \pm 0.008$ & $0.052 \pm 0.01$ & 17.0103 & $<0.0001^{*}$ & $0.067 \pm 0.025$ & 6.1029 & $0.035^{*}$ \\
\hline
\end{tabular}

Table 2. The mean number $\mathrm{km}^{-1} \pm \mathrm{SE}$ of Black Oystercatchers and Glaucous-winged Gulls detected on beach transects "Pre" (2008; $\mathrm{n}=16)$ and "Post" rat eradication $(2013 ; \mathrm{n}=16$ and 2019; $\mathrm{n}=16) .{ }^{\star} P$ is significant with $a<0.05$.

individual native vertebrate or plant species. It is more difficult to assess the long-term responses of entire communities or ecosystems, whose recoveries are frequently tied to the return of native species known to structure communities via their foraging patterns and other activities (but see ${ }^{4,45}$ ).

Based on previous work by Kurle et al. ${ }^{12}$ comparing rocky intertidal communities on islands with and without rats in the Aleutian archipelago, we hypothesized that rat removal would eventually return the marine rocky intertidal community on Hawadax Island to a three trophic level system with shorebirds as apex predators, instead of a four trophic level system with rats as apex predators, and thus change from algae- to invertebratedominated (Fig. 2). Consistent with this hypothesis, we found a dramatic shift in invertebrate and algal cover dominating the rocky intertidal community on Hawadax Island after rat eradication. Specifically, 11 years post rat eradication, we found: 1) a significant increase in percent cover of fleshy algae, 2) significant decreases in grazers of fleshy algae (isopods, limpets, and snails), as well as four other invertebrate groups (anemones, mussels, seastars, and sponges), and 3) significant increases in the shorebird predators (Glaucous-winged Gulls and Black Oystercatchers) of these intertidal invertebrates both five and 11 years post-rat eradication. Isopods were the only invertebrate that showed a statistically significant decrease in abundance five years post-rat eradication.

In rocky intertidal communities, marine birds can control abundances of invertebrate grazers via predation $^{46,47}$, and intertidal invertebrate herbivores reduce algal cover through grazing pressure ${ }^{48,49}$, leading, in some cases, to three level trophic cascades ${ }^{50,51}$ such as those observed on rat-free islands in Kurle et al. ${ }^{12}$. We expect other processes such as upwelling, temperature, recruitment, and currents also influenced the rocky intertidal community structure across the Aleutian Islands ${ }^{48,52}$. However, given the many examples of top-down control in rocky intertidal systems (see above), coupled with the patterns Kurle et al. ${ }^{12}$ observed across 23 islands spanning nearly the entire Aleutian Island chain, we are confident that the likely mechanism driving the rocky intertidal community structure on Hawadax Island is the extirpation of rats followed by the recovery of gulls and oystercatchers as the apex predators in a three level trophic cascade.

Abundances of gulls and oystercatchers were significantly greater in 2013 (2.3 and 5 times higher, respectively) compared with 2008, indicating passive recovery of the shorebird populations had already begun five years post rat-eradication. However, the intertidal data suggest this level or time for recovery was not sufficient to restore the rocky intertidal food web to a shorebird-mediated state more resembling that of a rat-free island. By 2019, gull and oystercatcher abundances had further increased to 2.9 and 9 times higher, respectively, than from 2008. These bird numbers are still lower than earlier measures from Aleutian Islands with no history of rat or fox invasions ${ }^{12}(n=89$ islands, oystercatchers $=0.25 \pm$ SD 0.44 and gulls $=17.64 \pm$ SD 60.88 birds per km of shoreline). However, the bird numbers between this study and Kurle et al. ${ }^{12}$ are not directly comparable as they derived their estimates from bird counts conducted by personnel circumnavigating islands in small boats rather than the land-based beach transect counts used here.

A few rocky intertidal species measured in this study did not follow the patterns observed in Kurle et al. ${ }^{12}$ between islands with and without rats. First, the percent cover of barnacles and tunicates were not different over time in this study, but their abundances were significantly less on islands without rats than on islands with rats in Kurle et al. ${ }^{12}$. These exceptions may simply reflect dietary choices by gulls and oystercatchers as they do not appear to eat tunicates, and barnacles make up only a small percentage of their preferred intertidal prey ${ }^{53-56}$. Kurle et al. ${ }^{12}$ surmised that the greater area covered by invertebrates not eaten by shorebirds on islands with rats was due to less algal cover and the resultant increased rocky intertidal substrate space available for invertebrate colonization. If this is the case, it may take more time for intertidal community differences related to competition, succession, and space availability to become measurable. In addition, the percent cover of geniculate algae in the intertidal showed no difference between 2008 and 2019. Coralline algal species in the North Pacific are fairly slow to colonize newly opened space ${ }^{57}$ and are initially outcompeted by fleshy algal species and certain invertebrates ${ }^{58}$, which could explain why their abundances did not change over the course of this study.

Further, we found no significant differences in the abundances of sea urchins, a known diet component for shorebirds, between pre- and post-eradication on Hawadax Island. Urchin abundance was not assessed in Kurle et al. ${ }^{12}$. Urchins are difficult to accurately measure in intertidal surveys as they are largely subtidal organisms, remaining submerged throughout a tide cycle by following the tidal flux or via confinement to shallow tide pools ${ }^{59}$. In addition, around the Aleutian Islands, urchin numbers are largely regulated by sea otter (Enhydra lutris) predaton. Sea otters around the Aleutian Islands have remained in steep decline since the 1990's, likely from predation by killer whales (Orcinus orca $)^{60}$, and are thus reduced across much of the Archipelago. Therefore, sea urchin abundances are high in many of the subtidal zones around the Aleutian Islands, including around Hawadax $^{61,62}$, and likely not controlled by bird predation.

A large marine heatwave ("The Blob") began in the Gulf of Alaska in fall 2013, spread south to Baja California, and caused warm sea surface temperature anomalies in the top $\sim 100 \mathrm{~m}$ of the ocean until April $2015^{63}$. Long-term 
monitoring of sites in the Gulf of Alaska (GOA) and the eastern Alaska Peninsula (EAP) documented significant intertidal changes related to The Blob, including decreases in sea stars, increases in mussels, and decreases in fleshy algae ${ }^{64}$. Coletti et al. ${ }^{64}$ related the reduction in sea stars to Sea Star Wasting Disease (SSWD), a syndrome causing mass mortality of sea stars from south-central Alaska to Baja California over the last decade. Mussel densities in the GOA and EAP then rose in response to a reduction in their sea star predators. The decreases in fleshy algal cover in the GOA and EAP were attributed to reductions in survival and/or recruitment of the brown algae Fucus distichus related to warmer than normal temperatures ${ }^{65}$. The range of SSWD detected in sea stars does not include the Aleutian Islands ${ }^{66}$, so is unlikely a factor in the decrease in sea stars or mussels we observed. And the trend of decreasing fleshy algal cover related to The Blob is the opposite of the increases we observed, making it unlikely its effects contributed to algal cover changes we observed on Hawadax.

Determining ecological community recovery following restoration is challenging but is aided by the clear definition of a goal, a quantified description of that state (e.g. equivalent monitoring data from experimental or natural controls), and an understanding of other environmental drivers that influence a restoration outcome. In addition, while species compositions are fairly uniform within intertidal communities across the Aleutian Islands, each island is subject to some variation in recruitment, reproduction, competition, predation, waveaction, and other factors influencing the densities and cover of intertidal species, further complicating our ability to assess the degree of intertidal community recovery 11 years after rat eradication on Hawadax Island. However, comparisons of the percentage change over time for the densities and percent cover values of intertidal organisms on Hawadax pre- vs. post-eradication are similar to those observed between islands with and without rats surveyed in 2002-2004 for Kurle et al. ${ }^{12}$ (Fig. 3, Supplementary Table 1), indicating a high degree of recovery from rat impacts in the rocky intertidal.

Across $60+$ years of invasion ecology as a discipline $e^{67,68}$, research has accumulated overwhelming evidence detailing the loss of biodiversity and other threats to native species and ecosystems posed by non-native invaders $^{69}$, especially on islands ${ }^{3}$. When mammalian invaders are removed from islands, conservation success, if measured at all, is generally tracked by how well populations of native (and largely terrestrial) species rebound ${ }^{8}$. However, less understood or even studied, are recoveries of entire communities, particularly nearshore marine systems, and the biological parameters a community must attain for it to be considered recovered (but $\operatorname{see}^{21,70}$ ). Community recovery is especially difficult to quantify as communities are host to a myriad of biological interactions, and invasive species can insert themselves into those interactions, shaping community structure in unexpected ways via direct and indirect mechanisms $\mathrm{s}^{29,45}$. Finally, the time required for community recovery after invasive species eradication is uncertain, as is the variability of recovery for different components of the system, requiring a long-term commitment to extensive monitoring.

Here, we move beyond demonstrating increases in native bird abundances after removal of invasive rats, a finding repeatedly shown across multiple studies detailing direct effects of rat eradication on native island species. Our long-term intertidal monitoring data show the changes in densities of rocky intertidal invertebrates and the percentage of intertidal area covered by fleshy algae and aggregating invertebrates after rats were removed from Hawadax Island largely followed the same patterns observed between rat-infested and rat-free islands surveyed in Kurle et al. ${ }^{12}$ indicating a high degree of passive recovery was achieved in a relatively short 11 years. With invasive rats removed, shorebirds have resumed their role as top predator, indirectly shaping the rocky intertidal community (Fig. 2B; see ${ }^{12}$ ).

More studies focused on understanding and measuring both direct and indirect impacts of invaders, and how communities respond following removal of those impacts, are needed to underscore the widespread conservation successes associated with invasive species eradication, especially on islands. In addition, our data demonstrate that continued eradication of introduced rats from other infested islands in the Aleutian Chain would add to increased bird and rocky intertidal community recoveries within the Alaska Maritime National Wildlife Refuge, thereby contributing to the Refuge's mission of restoration and protection of natural biodiversity on refuge lands.

\section{Methods}

Hawadax Island $\left(51.80^{\circ} \mathrm{N}, 178.30^{\circ} \mathrm{E}\right)$, part of the Alaska Maritime National Wildlife Refuge, is located within the Rat Islands group of the western Aleutian Islands (Fig. 2). The 2,780 ha (6,869 acres) island has steep cliffs along most of the coastline backed by rolling hills and plateaus rising to a small ridge of mountains with a peak elevation of $400 \mathrm{~m}$. There are more than 30 offshore rock stacks and several islets. The largest islet is approximately $4 \mathrm{ha}$ (10 acres) in size and is located $1.7 \mathrm{~km}$ off the southeast end of the island (Ayugadak Point). Hawadax Island is a designated Wilderness and has no inhabitants or human facilities.

Rats were introduced to different Aleutian Islands at different times. However, while one island (Little Kiska) became infested in 1990, the rest received rats before 1940 and as early as the $1700^{\prime} \mathrm{s}^{42}$. Thus, rat effects would currently be largely uniform across islands.

During September and October 2008, the U.S. Fish and Wildlife Service partnered with The Nature Conservancy and Island Conservation to restore seabird breeding habitat on Hawadax Island by removing introduced Norway rats using aerially applied cereal-based bait containing brodifacoum ${ }^{32}$. This was the first aerial rat eradication program conducted in Alaska ${ }^{32}$. Monitoring teams conducted biological surveys from June 1-20, 2008 (pre-eradication), and May 31-June 10, 2013 and June 1-16, 2019 (post-eradication), to coincide with early seasonal breeding activity for most native island bird species.

The protocols used in this study were approved by the Institutional Animal Care and Use Committee (IACUC) of the University of California, Santa Cruz (protocols Crold1004 and Crold1303). The research was performed in strict accordance with the guidelines and regulations in these protocols. Observers did not engage in any contact with the animals while recording their natural behavior and no biological samples were collected. 


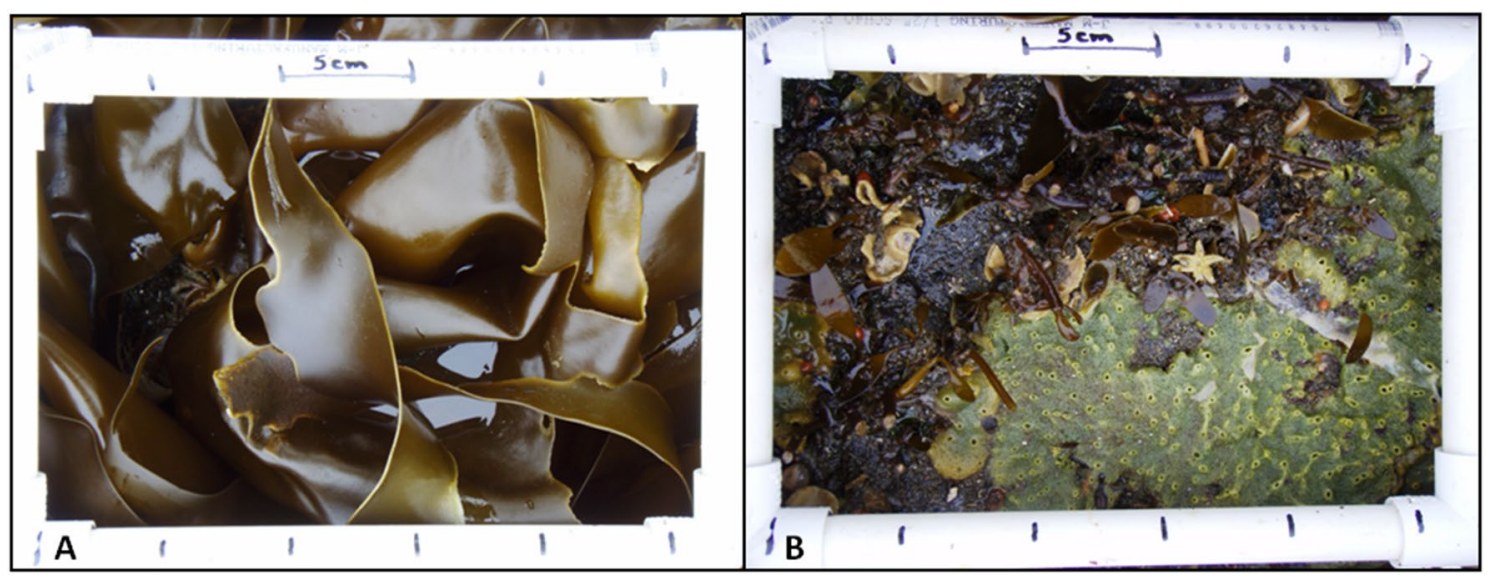

Figure 4. Example of digital photos of intertidal quadrats. A digital photo was taken first of the surface coverage of the plot (A). A second photo of the exact plot (B) was taken after the algal layer was removed to reveal the under-story community. Photos by J. Curl.

Intertidal community. Photo plots. We conducted surveys to describe the community structure of intertidal flora and fauna. We used methods similar to those developed by Kurle ${ }^{71}$, who previously conducted studies to document the impacts of Norway rats on marine bird densities and rocky intertidal communities in the Aleutian Islands, including Hawadax Island. In 2008 and 2013, we conducted surveys on eight beaches: five on the north side of the island, and three on the south side. In 2019, we revisited seven of the original eight beaches; due to time constraints, we were unable to survey Beach 6 on the south side of the island (Fig. 2).

At each beach, we conducted two transects in both the low and mid intertidal zones. The lower intertidal zones were dominated by algae from the genera Alaria and Laminaria, whereas the mid zones were dominated by algae from the genera Fucus and Halosaccion. For each $30 \mathrm{~m}$ transect, we took digital photos of seven, 365 $\mathrm{cm}^{2}$ quadrats, located at $5 \mathrm{~m}$ intervals. We took two photos every quadrat: the first of the surface coverage, and a second photo after the overlying algal layer was removed to reveal the understory community (Fig. 4).

Seasonal, logistic, financial, and low-tide constraints all limited our field time, precluding lengthy field identification of invertebrates to species. Our major goal with this limited field time was to get clear and accurate photos of our study plots to best replicate the earlier study of Kurle et al. ${ }^{12}$. As a result, we were not able to confidently identify our metrics to species, but instead relied upon the broader taxonomic categorization. While potentially interesting to have more taxonomic detail, the conclusions in our manuscript based upon the broad taxonomic categories are, we feel, robust.

We analyzed 2008 and 2013 intertidal photos using Adobe Photoshop 6.0. We used Adobe Photoshop Elements 2019 to analyze all digital photos taken in 2019 . We followed the same data analysis protocols in 2008, 2013 , and 2019. For all years, on each photo, we overlaid a digital $6 \times 9$ rectangular grid and calculated percent cover as the ratio of the number of each species lying below an intersection of the gridline to the total number of intersections within each grid. We calculated percent cover of sessile organisms (barnacles, sponges, and tunicates). We estimated the percent cover of larger algae (coralline algae and all fleshy algal species) by counting the percent cover of stipes that remained after the removal of the algal blades. We counted the number of individual mobile invertebrates (anemones, snails, limpets, mussels, urchins, and sea stars) in each photo to estimate density. We pooled data by beach for statistical analyses and compared the mean percent cover and mean number of individuals per $\mathrm{m}^{2}$ pre- (2008) and post- (2013 and 2019) eradication using t-tests $(\alpha=0.05)$.

Beach transects. Shorebirds, such as Black Oystercatchers and Glaucous-winged Gulls, are important predators of intertidal organisms ${ }^{53-56}$. To assess their relative abundance, we conducted beach surveys along the entire length of all accessible beaches $(n=16$; Fig. 2) on Hawadax Island. Detailed methods are presented in Croll et al. ${ }^{33}$ and are briefly summarized here. An observer slowly walked along each beach transect during morning hours whenever possible (0700-1100), counting all birds seen or heard between the water's edge and $50 \mathrm{~m}$ inland from the storm tide line. For each species, observers recorded aural and visual detections separately. Observers recorded the time and GPS location at the start and end of each transect. We measured the length of each transect following the contour of the beach between waypoints using ArcGIS $10.7^{72}$. We conducted four to five replicate surveys of each of the 16 beach transects to minimize effects of variation in time and sampling conditions. We calculated the relative abundances for Black Oystercatchers and Glaucous-winged Gulls by dividing the total count of birds detected per beach transect by the length of the transect (birds km${ }^{-1}$ ). We then averaged the five replicate surveys for each beach and used the averaged counts for each beach each year as a sample. We then compared pre- $(2008)$ and post-eradication $(2013,2019)$ results using nonparametric Van der Waerden tests, $\alpha=0.05$.

Assessing status of rocky intertidal community recovery. An island community may be considered recovered if the components are not significantly different from an unperturbed reference island ${ }^{73}$. To assess the degree to which the rocky intertidal on Hawadax Island may have recovered following rat eradication, we 
compared the percentage change over time for abundances and percent cover values of intertidal organisms and shorebirds on Hawadax Island pre- vs. post-rat eradication to those observed between islands with and without rats surveyed for Kurle et al. ${ }^{12}$.

Received: 16 September 2020; Accepted: 3 February 2021

Published online: 08 March 2021

\section{References}

1. Clavero, M., Brotons, L., Pons, P. \& Sol, D. Prominent role of invasive species in avian biodiversity loss. Biol. Conserv. 142, 2043-2049 (2009).

2. Clavero, M. \& García-Berthou, E. Homogenization dynamics and introduction routes of invasive freshwater fish in the Iberian Peninsula. Ecol. Appl. 16, 2313-2324 (2006).

3. Tershy, B. R., Shen, K.-W., Newton, K. M., Holmes, N. D. \& Croll, D. A. The Importance of islands for the protection of biological and linguistic diversity. Bioscience 65, 592-597 (2015).

4. Jones, H. P. Seabird islands take mere decades to recover following rat eradication. Ecol. Appl. 20, 2075-2080 (2010).

5. Wolf, C. A. et al. Invasive rat eradication strongly impacts plant recruitment on a tropical atoll. PLoS ONE 13, e0200743 (2018).

6. O’Dowd, D. J., Green, P. T. \& Lake, P. S. Invasional 'meltdown' on an oceanic island. Ecol. Lett. 6, 812-817 (2003).

7. Rogers, H. S. et al. Effects of an invasive predator cascade to plants via mutualism disruption. Nat. Commun. 8, 14557 (2017).

8. Jones, H. P. et al. Invasive mammal eradication on islands results in substantial conservation gains. Proc. Natl. Acad. Sci. 113, 4033-4038 (2016).

9. Towns, D. Eradications as reverse invasions: lessons from Pacific rat (Rattus exulans) removals on New Zealand islands. Biol. Invasions 11, 1719-1733 (2008).

10. Donlan, C. J., Croll, D. A. \& Tershy, B. R. Islands, exotic herbivores, and invasive plants: their roles in coastal California Restoration. Restor. Ecol. 11, 524-530 (2003).

11. Tabak, M. A., Poncet, S., Passfield, K., Goheen, J. R. \& del Rio, C. M. The ghost of invasives past: rat eradication and the community composition and energy flow of island bird communities. Ecosphere 7, e01442 (2016).

12. Kurle, C. M., Croll, D. A. \& Tershy, B. R. Introduced rats indirectly change marine rocky intertidal communities from algae- to invertebrate-dominated. Proc. Natl. Acad. Sci. 105, 3800-3804 (2008).

13. Thoresen, J. J. et al. Invasive rodents have multiple indirect effects on seabird island invertebrate food web structure. Ecol. Appl. 27, 1190-1198 (2017).

14. Russell, J. Indirect effects of introduced predators on seabird islands. In Seabird Islands: Ecology, Invasion, and Restoration (eds Mulder, C. et al.) (Oxford University Press, Oxford, 2011).

15. Le Corre, M. et al. Seabird recovery and vegetation dynamics after Norway rat eradication at Tromelin Island, western Indian Ocean. Biol. Conserv. 185, 85-94 (2015).

16. Doherty, T. S., Glen, A. S., Nimmo, D. G., Ritchie, E. G. \& Dickman, C. R. Invasive predators and global biodiversity loss. Proc. Natl. Acad. Sci. 113, 11261-11265 (2016).

17. Bellard, C., Genovesi, P. \& Jeschke, J. M. Global patterns in threats to vertebrates by biological invasions. Proc. R. Soc. B Biol. Sci. 283, 20152454 (2016).

18. Towns, D. R., Atkinson, I. A. E. \& Daugherty, C. H. Have the harmful effects of introduced rats on islands been exaggerated?. Biol. Invasions 8, 863-891 (2006).

19. Jones, H. P. et al. Severity of the effects of invasive rats on seabirds: a global review. Conserv. Biol. 22, 16-26 (2008).

20. Drake, D. R. et al. Direct Impacts of Seabird Predators on Island Biota other than Seabirds. In Seabird Islands: Ecology, Invasion, and Restoration Mulder (eds Anderson, C. P. H. et al.) 91-132 (Oxford University Press, Oxford, 2011). https://doi.org/10.1093/ acprof:osobl/9780199735693.003.0004.

21. Towns, D. R. et al. Impacts of Introduced Predators on Seabirds. In Seabird Islands: Ecology, Invasion, and Restoration Mulder (eds Anderson, C. P. H. et al.) 56-90 (Oxford University Press, Oxford, 2011). https://doi.org/10.1093/acprof:osobl/9780199735 693.003.0003.

22. Mulder, C. P. H., Anderson, W. B., Towns, D. R. \& Bellingham, P. J. Seabird Islands: Ecology, Invasion, and Restoration (Oxford University Press, Oxford, 2011).

23. Croll, D. A., Maron, J. L., Estes, J. A., Danner, E. M. \& Byrd, G. V. Introduced predators transform subarctic islands from grassland to Tundra. Science 307, 1959-1961 (2005).

24. Aslan, C. E., Zavaleta, E. S., Tershy, B. \& Croll, D. Mutualism disruption threatens global plant biodiversity: a systematic review. PLoS ONE 8, e66993 (2013).

25. DIISE. The Database of Island Invasive Species Eradications, developed by Island Conservation, Coastal Conservation Action Laboratory UCSC, IUCN SSC Invasive Species Specialist Group, University of Auckland and Landcare Research New Zealand. http://diise.islandconservation.org/ (2018).

26. Howald, G. et al. Invasive rodent eradication on islands. Conserv. Biol. 21, 1258-1268 (2007).

27. Keitt, B. et al. The Global Islands Invasive Vertebrate Eradication Database: A tool to improve and facilitate restoration of island ecosystems. In Island Invasives: Eradication and Management (eds Veitch, C. et al.) 4 (IUCN, Gland, 2011).

28. Nigro, K. M. et al. Stable isotope analysis as an early monitoring tool for community-scale effects of rat eradication. Restor. Ecol. 25, 1015-1025 (2017).

29. Courchamp, F. et al. Eradication of alien invasive species: surprise effects and conservation successes. In Island Invasives: Eradication and Management (eds Veitch, C. et al.) 285-289 (IUCN, Gland, 2011).

30. Jones, H. \& Schmitz, O. Rapid recovery of damaged ecosystems. PLoS ONE 4, e5653 (2009).

31. Jones, H. P. et al. Recovery and Restoration on Seabird Islands. In Seabird Islands: Ecology, Invasion, and Restoration (eds Mulder, C. et al.) (Oxford University Press, Oxford, 2011).

32. Buckelew, S., Byrd, V., Howald, G., MacLean, S. \& Sheppard, J. Preliminary ecosystem response following invasive Norway rat eradication on Rat Island, Aleutian Islands, Alaska. in Island Invasives: eradicaation and management 5 (IUCN, 2011).

33. Croll, D. A. et al. Passive recovery of an island bird community after rodent eradication. Biol. Invasions 18, $703-715$ (2016).

34. Hanson, K., Goos, M. \& Deines, F. G. Introduced arctic fox eradication at Rat Island (Aleutian Islands, Alaska, 1984).

35. ESRI. ESRI ArcMap 10.7.0.10450. (ESRI, 2020).

36. Lorvelec, O. \& Pascal, M. French attempts to eradicate non-indigenous mammals and their consequences for native biota. Biol. Invasions 7, 135-140 (2005).

37. Bellingham, P. J. et al. New Zealand island restoration: seabirds, predators, and the importance of history. N. Z. J. Ecol. 34, 115 (2010). 
38. St. Clair, J., Poncet, S., Sheehan, D., Szekely, T. \& Hilton, G. Responses of an island endemic invertebrate to rodent invasion and eradication. Anim. Conserv. 14, 66-73 (2011).

39. Monks, J. M., Monks, A. \& Towns, D. R. Correlated recovery of five lizard populations following eradication of invasive mammals. Biol. Invasions 16, 167-175 (2014).

40. Whitworth, D. L., Carter, H. R. \& Gress, F. Recovery of a threatened seabird after eradication of an introduced predator: Eight years of progress for Scripps's murrelet at Anacapa Island, California. Biol. Conserv. 162, 52-59 (2013).

41. Brooke, M. L. et al. Seabird population changes following mammal eradications on islands. Anim. Conserv. 21, 3-12 (2017).

42. Bailey, E. P. Introduction of foxes to Alaskan Islands: history, effects on Avifauna, and Eradication. (U.S. Dept. of the Interior, Fish and Wildlife Service; National Technical Information Service, distributor, 1993).

43. Byrd G. V., Trapp, J. L., \& Zeillemaker, C. F. Removal of Introduced Foxes: A Case Study in Restoration of Native Birds. in vol. 59 317-321 (1994).

44. Byrd, G. V., Bailey, E. P. \& Stahl, W. Restoration of island populations of black oystercatchers and pigeon guillemots by removing introduced foxes. Colon. Waterbirds 20, 253-260 (1997).

45. Ehrenfeld, J. G. Ecosystem consequences of biological invasions. Annu. Rev. Ecol. Evol. Syst. 41, 59-80 (2010).

46. Wootton, J. T. Indirect effects, prey susceptibility, and habitat selection: impacts of birds on limpets and algae. Ecology 73, 981-991 (1992).

47. Ellis, J. C., Chen, W., O’Keefe, B., Shulman, M. J. \& Witman, J. D. Predation by gulls on crabs in rocky intertidal and shallow subtidal zones of the Gulf of Maine. J. Exp. Mar. Biol. Ecol. 324, 31-43 (2005).

48. Menge, B. A. Top-down and bottom-up community regulation in marine rocky intertidal habitats. J. Exp. Mar. Biol. Ecol. 250, $257-289(2000)$.

49. Guerry, A. D., Menge, B. A. \& Dunmore, R. A. Effects of consumers and enrichment on abundance and diversity of benthic algae in a rocky intertidal community. J. Exp. Mar. Biol. Ecol. 369(2), 155-164 (2009).

50. Wootton, J. T. Effects of birds on sea urchins and algae: a lower-intertidal trophic cascade. Écoscience 2, 321-328 (1995).

51. Ellis, J. C., Shulman, M. J., Wood, M., Witman, J. D. \& Lozyniak, S. Regulation of intertidal food webs by avian predators on new england rocky shores. Ecology 88, 853-863 (2007).

52. Freidenburg, T. L., Menge, B. A., Halpin, P. M., Webster, M. \& Sutton-Grier, A. Cross-scale variation in top-down and bottom-up control of algal abundance. J. Exp. Mar. Biol. Ecol. 347(1-2), 8-29 (2007).

53. Webster, J. D. Feeding habits of the black oyster-catcher. Condor 43, 175-180 (1941).

54. Trapp, J. L. Variation in summer diet of Glaucous-winged Gulls in the Western Aleutian Islands: an ecological interpretation. Wilson Bull. 91, 412-419 (1979).

55. Irons, D. B., Anthony, R. G. \& Estes, J. A. Foraging strategies of Glaucous-winged gulls in a rocky intertidal community. Ecology 67, 1460-1474 (1986).

56. Davis, M. L., Elliott, J. E. \& Williams, T. D. Spatial and temporal variation in the dietary ecology of the Glaucous-winged Gull Larus Glaucescens in the Pacific Northwest. Mar. Ornithol. 43, 189-198 (2015).

57. Padilla, D. K. The importance of form: differences in competitive ability, resistance to consumers and environmental stress in an assemblage of coralline algae. J. Exp. Mar. Biol. Ecol. 79, 105-127 (1984).

58. Breitburg, D. Residual effects of grazing - inhibition of competitor recruitment by encrusting coralline algae. Ecology 65, 1136-1143 (1984).

59. Scheibling, R. E. \& Hatcher, B. G. Strongylocentrotus droebachiensis. In Developments in Aquaculture and Fisheries Science Vol. 38 (ed. Lawrence, J. M.) 381-412 (Elsevier, Amsterdam, 2013).

60. Estes, J., Tinker, M., Williams, T. \& Doak, D. F. Killer whale predation on sea otters linking oceanic and nearshore ecosystems | science. Science 282, 473-476 (1998).

61. Estes, J. A., Tinker, M. T. \& Bodkin, J. L. Using ecological function to develop recovery criteria for depleted species: sea otters and kelp forests in the aleutian archipelago. Conserv. Biol. 24, 852-860 (2010).

62. Stewart, N. L., Konar, B. \& Tinker, M. T. Testing the nutritional-limitation, predator-avoidance, and storm-avoidance hypotheses for restricted sea otter habitat use in the Aleutian Islands, Alaska. Oecologia 177, 645-655 (2015).

63. Gentemann, C. M., Fewings, M. R. \& García-Reyes, M. Satellite sea surface temperatures along the West Coast of the United States during the 2014-2016 northeast Pacific marine heat wave. Geophys Res Lett 44, 312-319 (2017).

64. Coletti, H. et al. Gulf Watch Alaska: Nearshore Ecosystems in the Gulf of Alaska. Exxon Valdez Oil Spill Restoration Project Annual Report (Restoration Project 18120114-H), Exxon Valdez Oil Spill Trustee Council, Anchorage, Alaska (2019).

65. Coletti, H. et al. Gulf Watch Alaska: Nearshore Ecosystems in the Gulf of Alaska. Exxon Valdez Oil Spill Restoration Project Annual Report (Restoration Project 18120114-H), Exxon Valdez Oil Spill Trustee Council, Anchorage, Alaska (2020).

66. Hewson, I. et al. Investigating the Complex Association Between Viral Ecology, Environment, and Northeast Pacific Sea Star Wasting. Front. Mar. Sci. 5, 2018 (2018).

67. Elton, C. S. The Ecology of Invasions by Animals and Plants (Springer, Berlin, 1958).

68. Richardson, D. M. \& Pysek, P. Fifty Years of Invasion Ecology: The Legacy of Charles Elton (Blackwell Publishing Ltd., Hoboken, 2008).

69. Courchamp, F. et al. Invasion biology: specific problems and possible solutions. Trends Ecol. Evol. 32, 13-22 (2017).

70. Cassini, M. H. A review of the critics of invasion biology. Biol. Rev. (2020).

71. Kurle, C. M. Description of the rocky intertidal communities and Norway rat behavior on Rat Island, Alaska in 2003. 21 (2005).

72. ESRI. ArcGIS 10.7. (ESRI, 2020).

73. Simberloff D. Reconstructing the ambiguous: can island ecosystems be restored? in Conservation Sciences Publication (New Zealand). no. 2. (1990).

\section{Acknowledgements}

Field assistance was provided by R. Dingler, S. Ebbert, R. Heinz, M. Mumm, A. Newman, R. ShaeningPokrasso, R. Stansbury, M. Vynne, and C. Wails. Additional field support was provided by S. Delehanty, S. Evans, R Galvan, and D. Schwartz. Invaluable research support was provided by Alaska Maritime National Wildlife Refuge staff, including V. Byrd, S. Delehanty, H. Renner, N. Rojek, A. Sowls, G. Siekaniec, L. Spitler, and the captain and crew of the R/V Tiglax, especially Captains Kevin Bell, John Faris, and Billy Pepper. Special thank you to G. Bentall for scientific illustrations. Many thanks to B. Menge and two anonymous reviewers for their contributions to improving our manuscript. We were supported in part by the US Fish and Wildlife Service and the National Fish and Wildlife Foundation. The views and conclusions contained in this document are those of the authors and should not be interpreted as representing the opinions or policies of the U.S. Government or the National Fish and Wildlife Foundation. Mention of trade names or commercial products does not imply endorsement by the U.S. Government or the National Fish and Wildlife Foundation. 


\section{Author contributions}

B.T., C.K., D.C., N.H., and S.B. conceived of the project and designed the study. C.W., J.C., J.P., M.B., and S.B. carried out the field work. J.C., J.S., K.Z., and M.B. analyzed the data and K.Z. created the figures and tables with advice from B.T., C.K., and D.C., C.K., D.C., and K.Z. wrote the manuscript with editing by B.T., C.W., G.H., J.C., J.S., J.P., J.W., M.B., N.H., and S.B. All authors read and approved the final manuscript.

\section{Competing interests}

The authors declare no competing interests.

\section{Additional information}

Supplementary Information The online version contains supplementary material available at https://doi. org/10.1038/s41598-021-84342-2.

Correspondence and requests for materials should be addressed to C.M.K. or D.A.C.

Reprints and permissions information is available at www.nature.com/reprints.

Publisher's note Springer Nature remains neutral with regard to jurisdictional claims in published maps and institutional affiliations.

(c) (i) Open Access This article is licensed under a Creative Commons Attribution 4.0 International License, which permits use, sharing, adaptation, distribution and reproduction in any medium or format, as long as you give appropriate credit to the original author(s) and the source, provide a link to the Creative Commons licence, and indicate if changes were made. The images or other third party material in this article are included in the article's Creative Commons licence, unless indicated otherwise in a credit line to the material. If material is not included in the article's Creative Commons licence and your intended use is not permitted by statutory regulation or exceeds the permitted use, you will need to obtain permission directly from the copyright holder. To view a copy of this licence, visit http://creativecommons.org/licenses/by/4.0/.

(C) The Author(s) 2021 